\title{
STUDIES ON COMPLETE AND PARTIAL ACIDULATION OF EPPAWELA APATITE
}

\author{
R. P. GUNAWARDANE \\ Department of Chemistry, University of Peradeniya, Peradeniya, Sri Lanka.
}

(Date of receipt : 27 April 1987)

(Date of acceptance : 27 July 1987)

\begin{abstract}
Acidulation of Eppawela apatite with hydrochloric acid and sulphuric acid has been investigated in an attempt to convert this rock phosphate to an acceptable $\mathrm{P}$-fertilizer using a simple and low cost method. Although direct acidulation with hydrochloric acid leads to a highly hygroscopic product, physical condition of this material can be improved by subsequent treatment with ammonia. Hydrochloric acid acidulation with $15-20 \% \mathrm{HCl}$ followed by $\mathrm{pH}$ adjustment using an alkali, leads to the precipitation of dicalcium phosphate, $\mathrm{CaHPO}$, which can readily be used as a $P$-fertilizer. Use of ammonia and ammonium salts has an added advantage in that the product contains nitrogen in addition to phosphons. Physical condition of $\mathrm{H}_{2} \mathrm{SO}_{4}-$ acidulated material is superior and the fertilizer value of this product is dependent on the extent of acidulation. Since the cost of this product depends mainly on the cost of $\mathrm{H}_{2} \mathrm{SO}_{4}$, partial acidulation with sulphuric acid seems to be a potentially useful and economical method. $50 \%$ acidulation with sulphuric acid to produce partially acidulated phosphate rock (PAPR-50) containing $17 \% \mathrm{wt}$ available $\mathrm{P}_{2} \mathrm{O}_{5}$ and $25 \%$ wt total $\mathrm{P}_{2} \mathrm{O}_{5}$ appears to be suitable.
\end{abstract}

\section{Introduction}

Rock phosphate reserves ${ }^{6}$ at Eppawela in Sri Lanka can be represented as chlorfluorapatite ${ }^{3} \mathrm{Ca}_{5}\left(\mathrm{PO}_{4}\right)_{3}(\mathrm{Cl}, \mathrm{F})$. It has been reported ${ }^{8}$ that the use of Eppawela apatite as a phosphatic fertilizer is limited due to its very low solubility. Its water solubility is about $0.5 \%$ wt $\mathrm{P}_{2} \mathrm{O}_{5}$, while $2 \%$ citric acid solubility ${ }^{3}$ is in the range $5-6 \%$ wt $\mathrm{P}_{2} \mathrm{O}_{5}$. Thus, it is not generally recommended for direct application especially for short term crops such as paddy. As such, attempts have been made to convert this mineral to more soluble phosphate fertilizers by low temperature sintering methods. ${ }^{3,4,5}$

Acidulation is one of the common methods ${ }^{10}$ to convert rock phosphate to more soluble phosphate fertilizers. Most commonly rock phosphate is treated with either $\mathrm{H}_{2} \mathrm{SO}_{4}$ or $\mathrm{H}_{3} \mathrm{PO}_{4}$ to produce singlesuperphosphate (SSP) or triplesuperphosphate (TSP) respectively. SSP contains about $20 \%$ wt available $\mathrm{P}_{2} \mathrm{O}_{5}$ while TSP possesses much higher available phosphorus content $\left(\sim 45 \%\right.$ wt $\left.\mathrm{P}_{2} \mathrm{O}_{5}\right)$.

Eppawela rock phosphate is believed to be of igneous origin ${ }^{6}$ and contains more chlorine ${ }^{3}$ than fluorine. Its total $\mathrm{P}_{2} \mathrm{O}_{5}$ content is rather high, the average being about $36 \%$. It has a relatively high and a variable content 
(4-10\%) of total $\mathrm{Al}_{2} \mathrm{O}_{3}$ and $\mathrm{Fe}_{2} \mathrm{O}_{3}$. Although these special chemical features of Eppawela apatite could make it difficult to use it for conventional acidulation processes, it is of interest to investigate the basic aspects of its acidulation reaction with locally produced mineral acids such as hydrochloric and sulphuric acids.

In the present study complete and partial acidulation of Eppawela apatite with hydrochloric acid and sulphuric acid has been investigated in an attempt to convert Eppawela rock phosphate to a more soluble fertilizer grade phosphate material.

\section{Experimental}

Two rock phosphate samples labelled I and II have been used in the present study. Sample I was collected from one of the hillocks in the northern part of the "leached zone" of the apatite deposit at Eppawela, Sri Lanka. This rock sample was crushed, powdered and sieved (100 mesh) for subsequent investigation. Sample II is a sample of commercially available powdered (90\% passing through 100 mesh) Eppawela rock phosphate.

\subsection{Chemical analysis}

Analysis of the metallic elements and silicon has been performed using a $\mathrm{X}$-ray fluorescence spectrometer. Total $\mathrm{P}_{2} \mathrm{O}_{5}$ has been determined by the $\mathrm{X}$-ray fluorescence as well as by the vanadomolybdate method. ${ }^{9}$ Analyses for fluoride have been made using Orion model 94-09 fluoride ion electrode $^{1}$ against a Beckman type R.L.B. calomel reference electrode. The samples were dissolved in $5 \mathrm{M}$ hydrochloric acid for this analysis. Chlorine analyses were made by dissolving the samples in $1: 1$ nitric acid and titrating it with standard $0.05 \mathrm{M}$ silver nitrate to a potentiometric end point. Table 1 shows the results of chemical analysis of the two samples for their major constituents and trace elements. Phases present in some products were identified by using powder $\mathrm{X}$-ray diffraction with $\mathrm{Cu} \mathrm{K} \alpha$ radiation.

\section{$2.2 \mathrm{HCl}$ acidulation}

Rock phosphate samples were treated with hydrochloric acid of known strength and stirred vigorously for 30 minutes in beakers. The resulting slurry was allowed to stand for 6 hours and then transferred to porcelain dishes for curing. After curing period, the product was dried at $100^{\circ} \mathrm{C}$.

For dicalcium phosphate precipitation, the rock samples have been mechanically stirred with hydrochloric acid for $6-8$ hours. The $\mathrm{pH}$ of the resulting solution was adjusted in the range $5-7$ using aqueous sodium 
Table 1. Analytical data of Eppawela apatite

(i) Partial Chemical Analysis: (in wt\%)

\begin{tabular}{lcc}
\hline & Apatite (I) & Commercial apatite (II) \\
\hline $\mathrm{CaO}$ & 46.60 & 43.50 \\
$\mathrm{P}_{2} \mathrm{O}_{5}$ & 35.30 & 32.80 \\
$\mathrm{Fe}_{2} \mathrm{O}_{3}$ & 3.80 & 5.00 \\
$\mathrm{Al}_{2} \mathrm{O}_{3}$ & 0.74 & 2.60 \\
$\mathrm{Cl}$ & 2.20 & 2.03 \\
$\mathrm{~F}$ & 1.70 & 1.60 \\
$\mathrm{SiO}_{2}$ & 0.43 & 0.79 \\
$\mathrm{SrO}$ & 0.38 & 0.34 \\
\end{tabular}

(ii) Trace Elements Analysis: (in ppm)

\begin{tabular}{lrrlrrr}
\hline Element & I & II & Element & I & II \\
\hline $\mathrm{K}$ & 300 & 500 & $\mathrm{Cu}$ & 307 & 157 \\
$\mathrm{Ba}$ & 316 & 1178 & $\mathrm{La}$ & 470 & 438 \\
$\mathrm{Co}$ & 8 & 10 & $\mathrm{Mn}$ & 500 & 2300 \\
$\mathrm{Cr}$ & 20 & 21 & $\mathrm{Ti}$ & 10 & 200 \\
$\mathrm{Mg}$ & 300 & 400 & $\mathrm{Na}$ & 600 & 1100 \\
$\mathrm{Zn}$ & 309 & 239 & $\mathrm{Zr}$ & 9 & 12 \\
$\mathrm{Y}$ & 94 & 108 & $\mathrm{Ni}$ & 23 & 26 \\
$\mathrm{Sr}$ & 3217 & 2936 & $\mathrm{~W}$ & 8 & 5 \\
$\mathrm{As}$ & 23 & 27 & $\mathrm{~Pb}$ & 111 & 140 \\
$\mathrm{~V}$ & 46 & 81 & & & \\
\hline
\end{tabular}

NOTE: I - A representative sample from the 'leached zone' at Eppawela. II - A sample of commercially available powdered Eppawela apatite. 
hydroxide, lime or ammonia. After the precipitation is complete, the product was filtered under suction and dried at $100^{\circ} \mathrm{C}$ prior to analysis.

\section{$2.3 \mathrm{H}_{2} \mathrm{SO}_{4}$ acidulation}

Sulphuric acid acidulation was performed similar to hydrochloric acid acidulation but in this case drying was not necessary. During the curing period the acidulated product gradually transforms into a dry powder.

\subsection{Estimation of phosphorus}

Water and $2 \%$ citric acid soluble $\mathrm{P}_{2} \mathrm{O}_{5}$ contents of the samples have been determined $^{11}$ by using about $1 \mathrm{~g}$ samples. These were extracted in $250 \mathrm{ml}$ reagent bottles with $100 \mathrm{ml}$ of distilled water or $2 \%$ citric acid solution using a mechanical shaker operating at about 250 oscillations per minute for 30 minutes. The total $\mathrm{P}_{2} \mathrm{O}_{5}$ contents have been determined by extracting the samples with conc. $\mathrm{HCl}$. The extracts were analysed for phosphorus by the vanadomolybdate ${ }^{9}$ method using Corning colorimeter model 253 at a wavelength of $460 \mathrm{~nm}$.

\section{Results and Discussion}

\subsection{Direct acidulation with $\mathrm{HCl}$}

Acidulation reaction for the complete $(100 \%)$ acidulation of apatite may be represented as follows.

$2 \mathrm{Ca}_{5}\left(\mathrm{PO}_{4}\right)_{3}(\mathrm{X})+14 \mathrm{HCl} \longrightarrow 3 \mathrm{Ca}\left(\mathrm{H}_{2} \mathrm{PO}_{4}\right)_{2}+7 \mathrm{CaCl}_{2}+2 \mathrm{HX}$

Several side reactions may also occur depending on the other components and the impurities present in the rock. As such, the acid requirement for acidulation in general is calculated by considering the nature and amounts of impurities present and the total $\mathrm{P}_{2} \mathrm{O}_{5}$ content of the rock.

Variation of available $\mathrm{P}_{2} \mathrm{O}_{5}$ with the acid concentration for $100 \%$ and $60 \%$ acidulations is shown in Figure 1 . In both cases the available $\mathrm{P}_{2} \mathrm{O}_{5}$ increases with increase in concentration up to about $18 \%$ and further increase in concentration does not have any effect on the available phosphorus content. Thus, the optimum concentration for $\mathrm{HCl}$ acidulation is in the range $15-20 \%$. Therefore, it appears that dilute hydrochloric acid solution could be conveniently used for the acidulation process. Completely acidulated product of rock sample I contains $\sim 19 \%$ available $\mathrm{P}_{2} \mathrm{O}_{5}$ while 


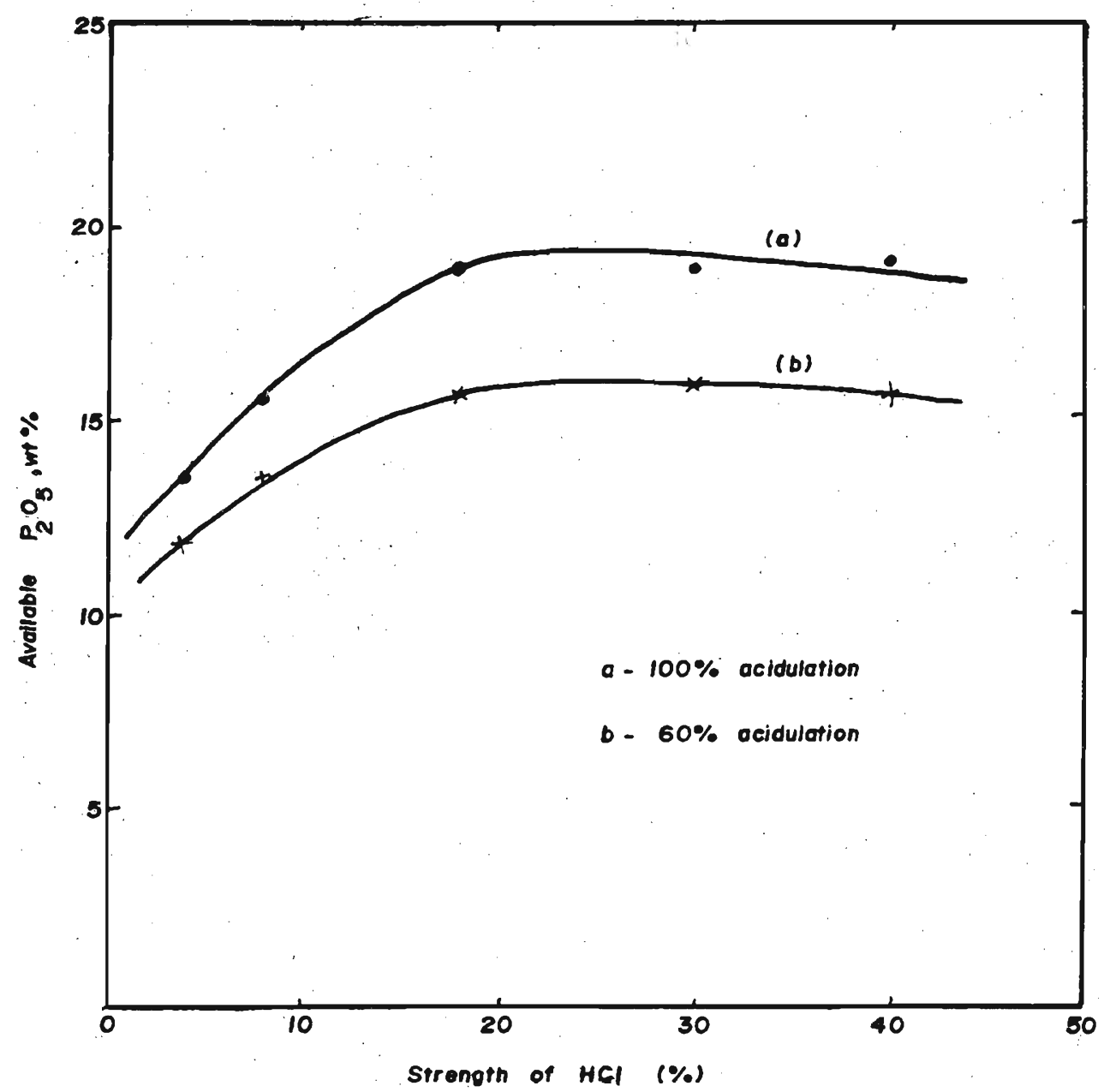

Figure 1. Variation of available phosphorus content of $\mathrm{HCl}$-acidulated product with the acid concentration. 
commercial apatite (sample II) gave a product containing $\sim 17 \%$ wt $\mathrm{P}_{2} \mathrm{O}_{5}$. However, a product containing a maximum of $\sim 20 \%$ available $\mathrm{P}_{2} \mathrm{O}_{5}$ can be obtained by increasing the amount of acid added. On the other hand partially acidulated (60\%) product contains $14-16 \%$ wt available $\mathrm{P}_{2} \mathrm{O}_{5}$.

Major problem of $\mathrm{HCl}$ acidulation is due to the fact that the product contains a large amount of highly hygroscopic calcium chloride. The presence of calcium chloride leads to problems of drying, storage and transport of the fertilizer. However, it has been observed in the present study that the hygroscopic nature of the product can be considerably reduced and the physical properties improved by the treatment of the $\mathrm{HCl}$ acidulated product with aqueous ammonia or a suitable ammonium salt.

Since both monocalcium phosphate, $\mathrm{Ca}\left(\mathrm{H}_{2} \mathrm{PO}_{4}\right)_{2}$, and calcium chloride are highly water soluble it is rather difficult to separate one from the other by a simple and inexpensive technique. As an alternative, it may be possible to convert apatite to dicalcium phosphate $\left(\mathrm{CaHPO}_{4}\right)$ which is water insoluble (Table 5) but citric acid soluble making its phosphorus available to the plants. Thus, extremely water soluble calcium chloride can be conveniently removed from the product.

\section{2 $\mathrm{CaHPO}_{4}$ precipitation}

The optimum conditions suitable for the precipitation of dicalcium phosphate, $\mathrm{CaHPO}_{4}$, from acidic phosphate solutions have been determined ${ }^{7}$ previously. The optimum $\mathrm{pH}$ for this precipitation is found to be in the range $5-7$. The variation of available $\mathrm{P}_{2} \mathrm{O}_{5}$ of the product with the precipitation $\mathrm{pH}$ is shown in Figure 2. This confirms the optimum $\mathrm{pH}$ for the precipitation as $5-7$. The precipitation begins around $\mathrm{pH} 4$ and when the $\mathrm{pH}$ is increased beyond 7 , citric acid solubility of the product decreases indicating the conversion of $\mathrm{CaHPO}_{4}$ to $\mathrm{Ca}_{3}\left(\mathrm{PO}_{4}\right)_{2}$.

$\mathrm{pH}$ adjustment in the acid extracts has been done using aqueous $\mathrm{NaOH}$ lime or ammonia. Table 2 shows the results of dicalcium phosphate precipitation after $60 \%$ and $100 \%$ acidulation followed by $\mathrm{pH}$ adjustment using aqueous $\mathrm{NaOH}$. Both sets of results show that there is an increase of $2 \%$ citric acid solubility of the product with increase in acid concentration up to $18 \%$. $60 \%$ acidulation with $18 \% \mathrm{HCl}$ followed by neutralization with aqueous $\mathrm{NaOH}$ yielded a product containing $23-25 \%$ available $\mathrm{P}_{2} \mathrm{O}_{5}$. The rock sample II, however, yielded a product containing slightly lower $(\sim 21 \%)$ available $\mathrm{P}_{2} \mathrm{O}_{5}$ content. The major constituent in the dried product was identified as dicalcium phosphate $\left(\mathrm{CaHPO}_{4}\right)$ by powder X-ray diffraction. Tricalcium phosphate, $\mathrm{Ca}_{3}\left(\mathrm{PO}_{4}\right)_{2}$, and apatite also have been identified in the product. 


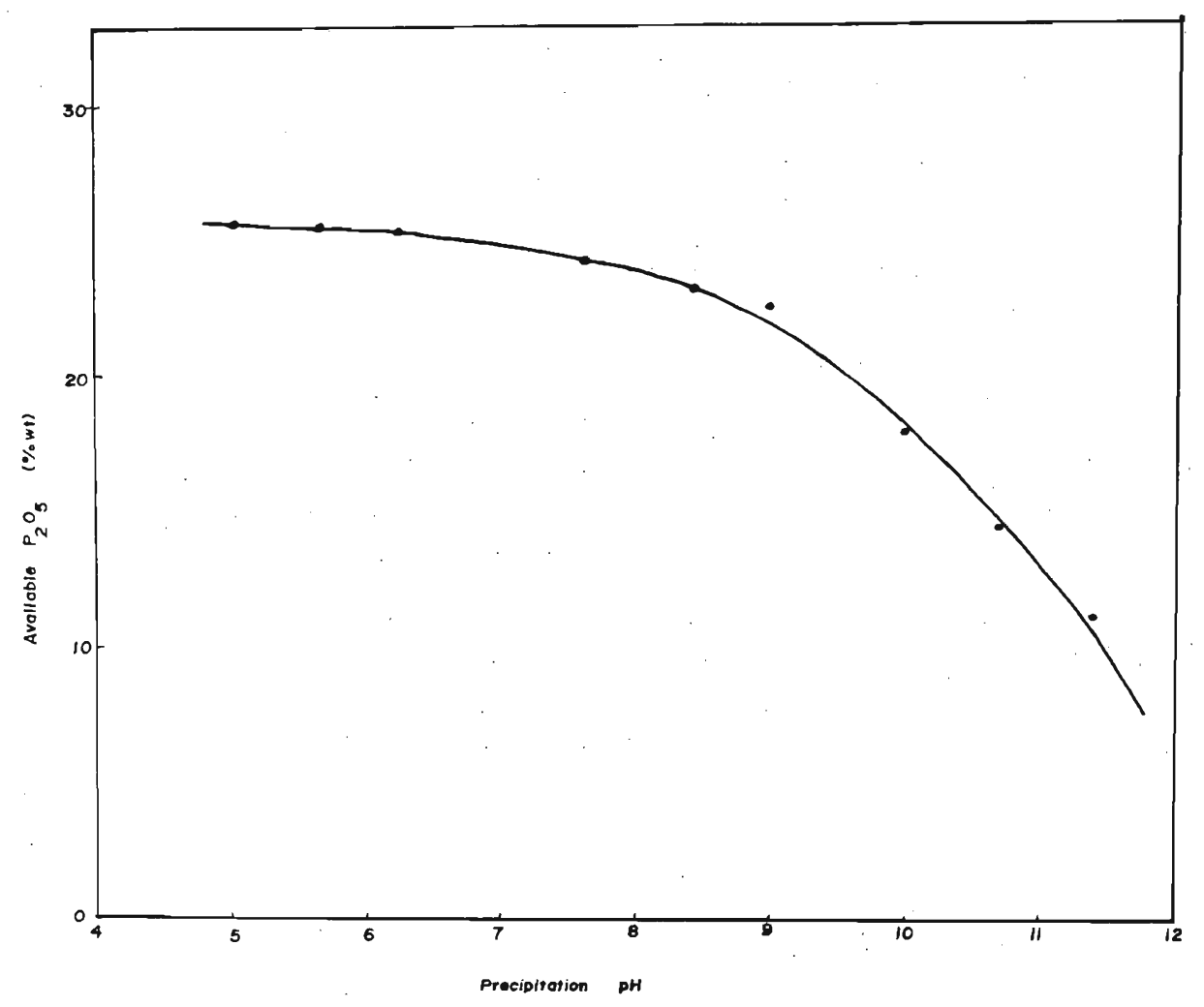

Figure 2. Effect of precipitation $\mathrm{pH}$ on the available phosphorus content of the precip1tated product. 
Table 2. Results of $\mathrm{HCl}$ acidulation followed by precipitation.

\begin{tabular}{llll}
\hline Strength of acid & $\begin{array}{l}\text { Extent of } \\
\text { acidulation }\end{array}$ & $\begin{array}{l}2 \% \text { citric acid } \\
\text { soluble } \mathrm{P}_{2} \mathrm{O}_{5} \text { wt. } \%\end{array}$ & $\begin{array}{c}\mathrm{P}_{2} \mathrm{O}_{5} \text { wt. \% } \\
\text { in the filtrate }\end{array}$ \\
\hline $4 \%$ & $60 \%$ & 21.3 & 0.5 \\
$8 \%$ & $60 \%$ & 22.2 & 1.6 \\
$18 \%$ & $60 \%$ & 22.9 & 1.9 \\
$4 \%$ & $100 \%$ & 23.6 & 1.2 \\
$8 \%$ & $100 \%$ & 24.5 & 1.8 \\
\hline
\end{tabular}

Note: Base used is aqueous sodium hydroxide

Possibility of using lime to adjust the $\mathrm{pH}$ has been attempted. But in this case the product was found to contain about $16 \%$ available $\mathrm{P}_{2} \mathrm{O}_{5}$. Relatively large quantities of $\mathrm{Ca}_{3}\left(\mathrm{PO}_{4}\right)_{2}$ and hydroxyapatite in addition to $\mathrm{CaHPO}_{4}$ have been observed in the product obtained using lime. Thus it is rather difficult to control the reaction for the preferential precipitation of $\mathrm{CaHPO}_{4}$ in the presence of lime. On the other hand, ammonia was found to be an acceptable $\mathrm{pH}$ controlling agent. It has an added advantage in that the product contains appreciable amount of nitrogen in addition to phosphorus $\left(\sim 26 \%\right.$ wt available $\left.\mathrm{P}_{2} \mathrm{O}_{5}\right)$. The following reaction may occur during the ammoniation facilitating the precipitation of $\mathrm{CaHPO}_{4}$.

$$
\mathrm{Ca}\left(\mathrm{H}_{2} \mathrm{PO}_{4}\right)_{2}+\mathrm{NH}_{3} \longrightarrow \mathrm{CaHPO}_{4}+\mathrm{NH}_{4} \mathrm{H}_{2} \mathrm{PO}_{4} .
$$

\subsection{Acidulation with sulphuric acid}

Figure 3 shows the variation of the extent of conversion with the concentration of $\mathrm{H}_{2} \mathrm{SO}_{4}$ used in the acidulation. All three curves representing $100 \%$, $75 \%$ and $50 \%$ acidulation reactions show a maximum around $70 \% \mathrm{H}_{2} \mathrm{SO}_{4}$. Thus the optimum concentration for complete and partial acidulation of apatite with $\mathrm{H}_{2} \mathrm{SO}_{4}$ is in the range $65-70 \%$. As such, all the $\mathrm{H}_{2} \mathrm{SO}_{4}$ acidulation experiments have been performed using $70 \%$ sulphuric acid in the present study. 


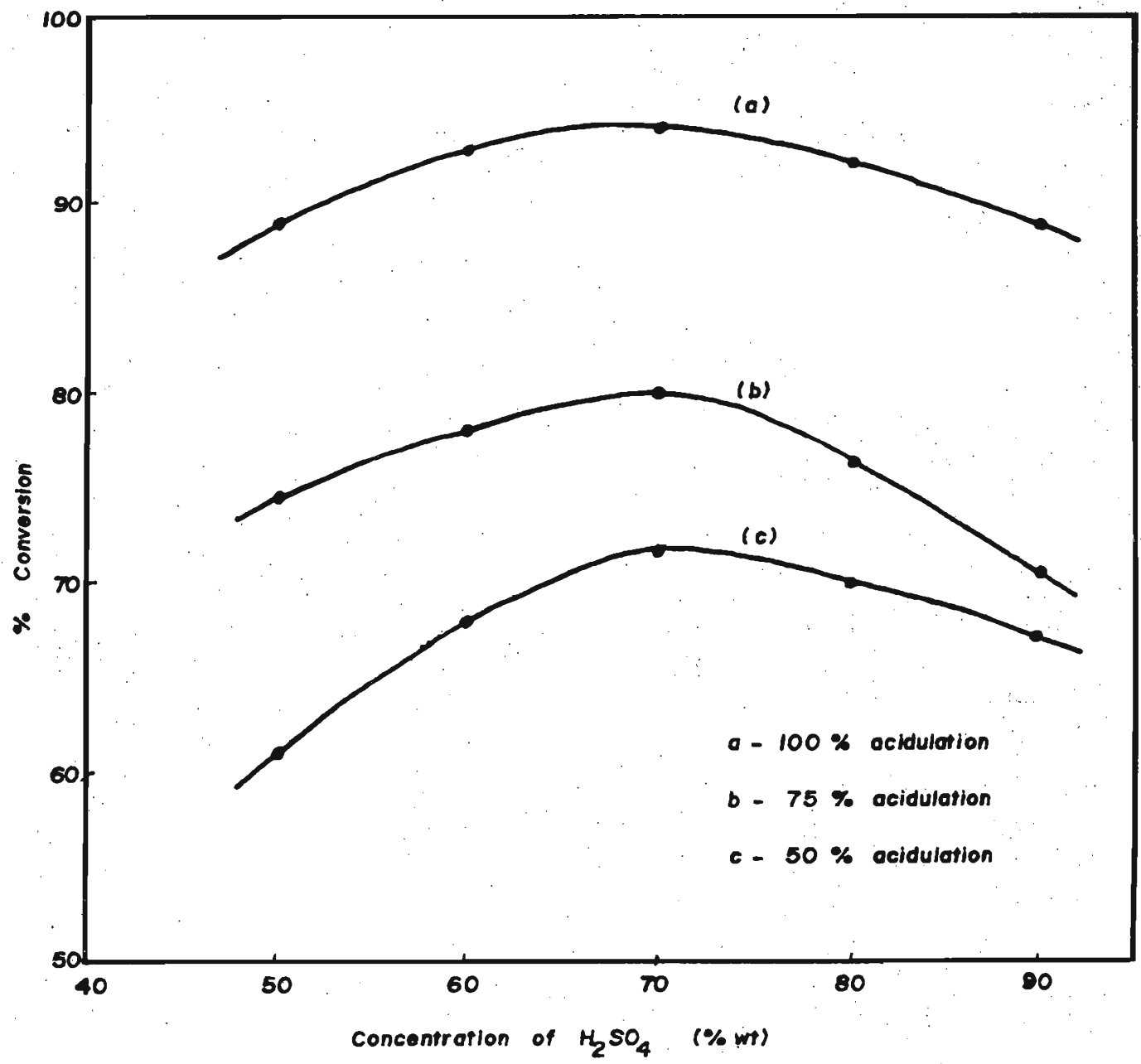

Figure 3. Effect of concentration of $\mathrm{H}_{2} \mathrm{SO}_{4}$ on the extent of conversion. 
Table 3. Variation of available $\mathrm{P}_{2} \mathrm{O}_{5}$ content with the extent of $\mathrm{H}_{2} \mathrm{SO}_{4}$ acidulation.

\begin{tabular}{lccc}
\hline $\begin{array}{l}\text { Extent of } \\
\text { acidulation }\end{array}$ & $\begin{array}{l}\text { Total } \mathrm{P}_{2} \mathrm{O}_{5} \\
\% \text { wt. }\end{array}$ & $\begin{array}{l}\text { Water soluble } \\
\mathrm{P}_{2} \mathrm{O}_{5} \% \text { wt. }\end{array}$ & $\begin{array}{l}\text { 2\% citric acid } \\
\text { soluble } \mathrm{P}_{2} \mathrm{O}_{5} \% \text { wt. }\end{array}$ \\
\hline $100 \%$ & 21.7 & 19.6 & 20.8 \\
$80 \%$ & 22.6 & 16.3 & 19.0 \\
$60 \%$ & 24.4 & 12.1 & 18.0 \\
$50 \%$ & 25.6 & 10.5 & 17.1 \\
$30 \%$ & 28.6 & 6.1 & 14.8 \\
\hline
\end{tabular}

Note: Original rock phosphate contained $35.3 \%$ wt. total $\mathrm{P}_{2} \mathrm{O}_{5}$; curing period $=4$ weeks

$\mathrm{P}_{2} \mathrm{O}_{5}$ contents of the products obtained by complete and partial acidulation of Eppawela apatite are given in Table 3. The variation of total, available and water soluble $\mathrm{P}_{2} \mathrm{O}_{5}$ contents with the extent of acidulation are shown in the Figure 4. SSP produced $(100 \%$ acidulation) from apatite contains $20.8 \%$ available $\mathrm{P}_{2} \mathrm{O}_{5}$, of which $19.6 \%$ is water soluble. The available $\mathrm{P}_{2} \mathrm{O}_{5}$ contents decrease with decrease in the extent of acidulation. $50-60 \%$ acidulated product contains a reasonably high value of available $\mathrm{P}_{2} \mathrm{O}_{5}$. (17-18\% wt), although the amount of acid added is reduced by $40-50 \%$. Furthermore, partially acidulated product contains much higher total $\mathrm{P}_{2} \mathrm{O}_{5}$ content (Figure 4 ) which will eventually be available to the soil and to the plants.

Available $\mathrm{P}_{2} \mathrm{O}_{5}$ contents of the product obtained after different curing periods are shown in Table 4. Effect of curing period on the product for $100 \%$ and $60 \%$ acidulations are shown in Figure 5. The results indicate that for $60 \%$ acidulation the optimum curing period is about 3-4 weeks while for SSP production 5-6 weeks curing is required. Thus, partial acidulation has an added advantage of having a less curing period.

$50 \%$ acidulated product was found to contain unreacted apatite, monocalcium phosphate and trace amounts of dicalcium phosphate by powder X-ray diffraction. The product was not found to be sticky. However, a suitable treatment may be necessary if the product obtained in a commercial scale preparation is found to be sticky. 


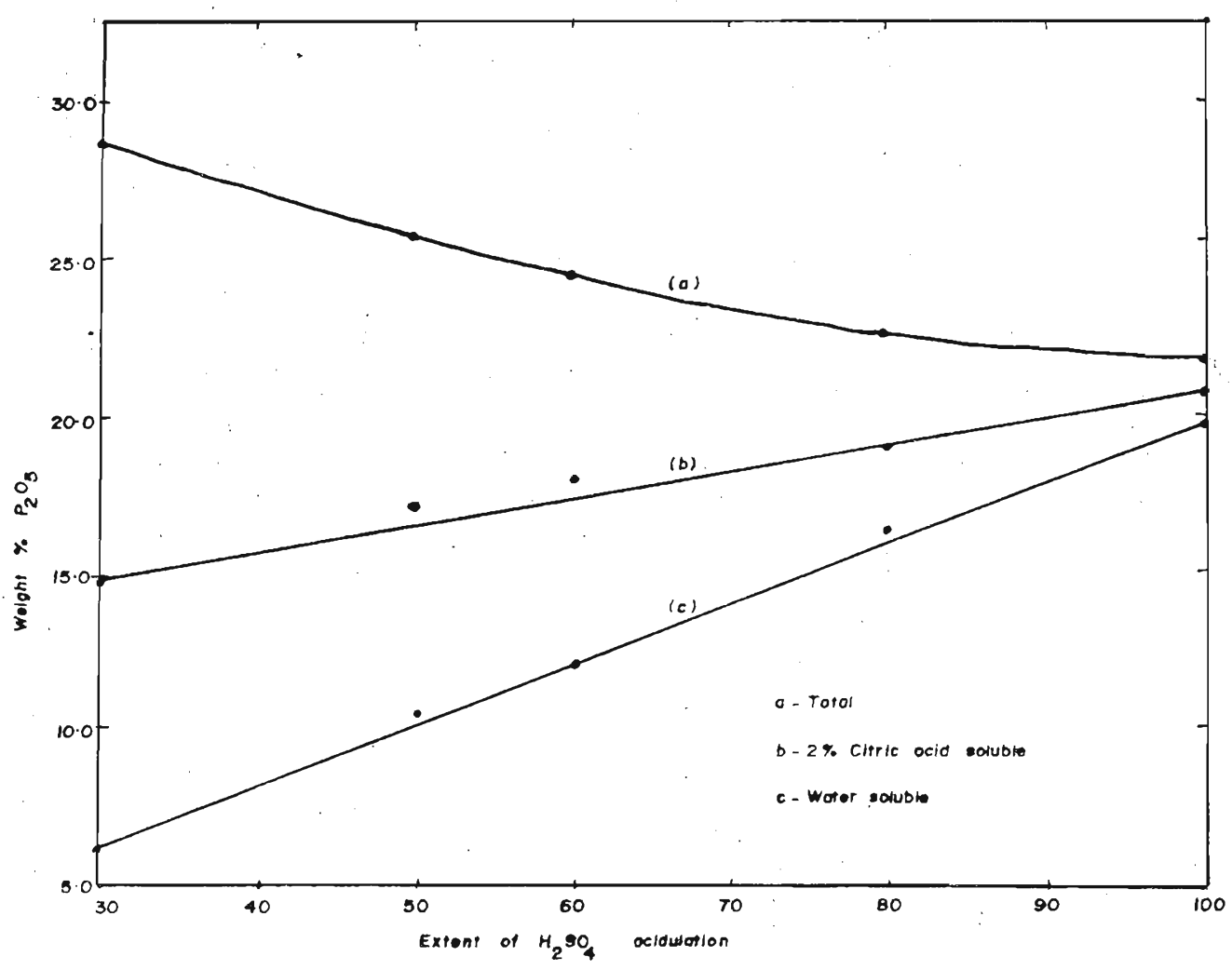

Figure 4. Variation of total, available and water soluble phosphorus contents with the extent of $\mathrm{H}_{2} \mathrm{SO}_{4}$-acidulation. 
Table 4. $\quad \mathrm{H}_{2} \mathrm{SO}_{4}$ acidulation : Effect of curing time on the availble $\mathrm{P}_{2} \mathrm{O}_{5}$ content.

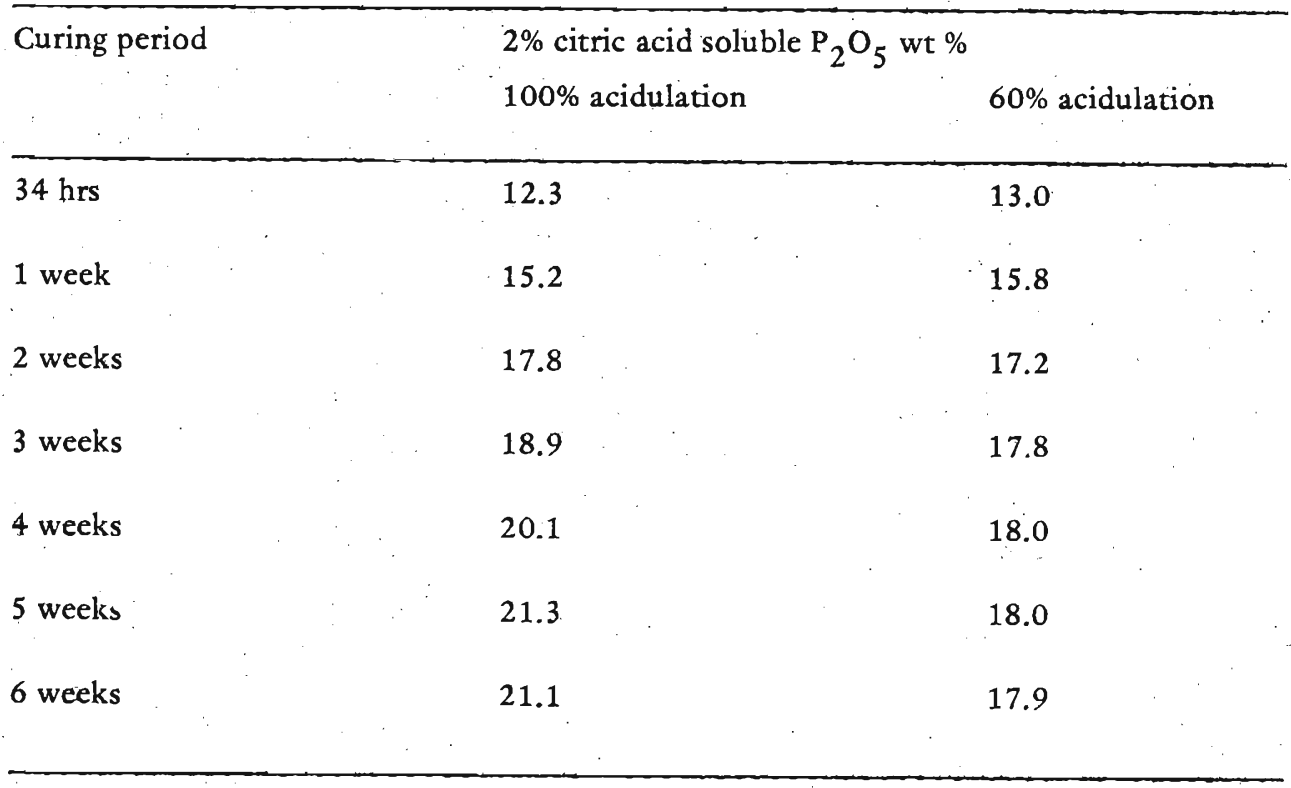

Table 5. Phosphorus contents of some calcium phosphates

\begin{tabular}{|c|c|c|c|c|c|}
\hline Sample & $\begin{array}{l}\text { Total } \mathrm{P}_{2} \mathrm{O}_{5} \\
\text { wt } \%\end{array}$ & $\begin{array}{l}\text { Water soluble } \\
\mathrm{P}_{2} \mathrm{O}_{5} \text { wt \% }\end{array}$ & $\begin{array}{l}2 \% \text { citric } \\
\text { soluble } \mathrm{P}\end{array}$ & $\mathrm{P}_{2} \mathrm{O}_{5} \mathrm{wt}$ & wt \% \\
\hline Rock phosphate I & 35.3 & 0.5 & 5.8 & & \\
\hline Rock phosphate II & 32.8 & 0.4 & 5.2 & & \\
\hline $\begin{array}{l}\text { Hydroxyapatite } \\
\mathrm{Ca}_{5}\left(\mathrm{PO}_{4}\right)_{3} \mathrm{OH}\end{array}$ & 42.3 & 0.7 & 16.2 & & \\
\hline $\begin{array}{l}\text { Monocalcium phosphate } \\
\mathrm{Ca}\left(\mathrm{H}_{2} \mathrm{PO}_{4}\right)_{2}\end{array}$ & 60.6 & 58.3 & 60.4 & & \\
\hline $\begin{array}{l}\text { Dicalcium phosphate } \\
\mathrm{CaHPO}_{4}\end{array}$ & 52.1 & 1.3 & 44.4 & & \\
\hline $\begin{array}{l}\text { Tricalcium phosphate } \\
\mathrm{Ca}_{3}\left(\mathrm{PO}_{4}\right)_{2}\end{array}$ & 45.8 & 0.9 & 34.0 & & \\
\hline
\end{tabular}




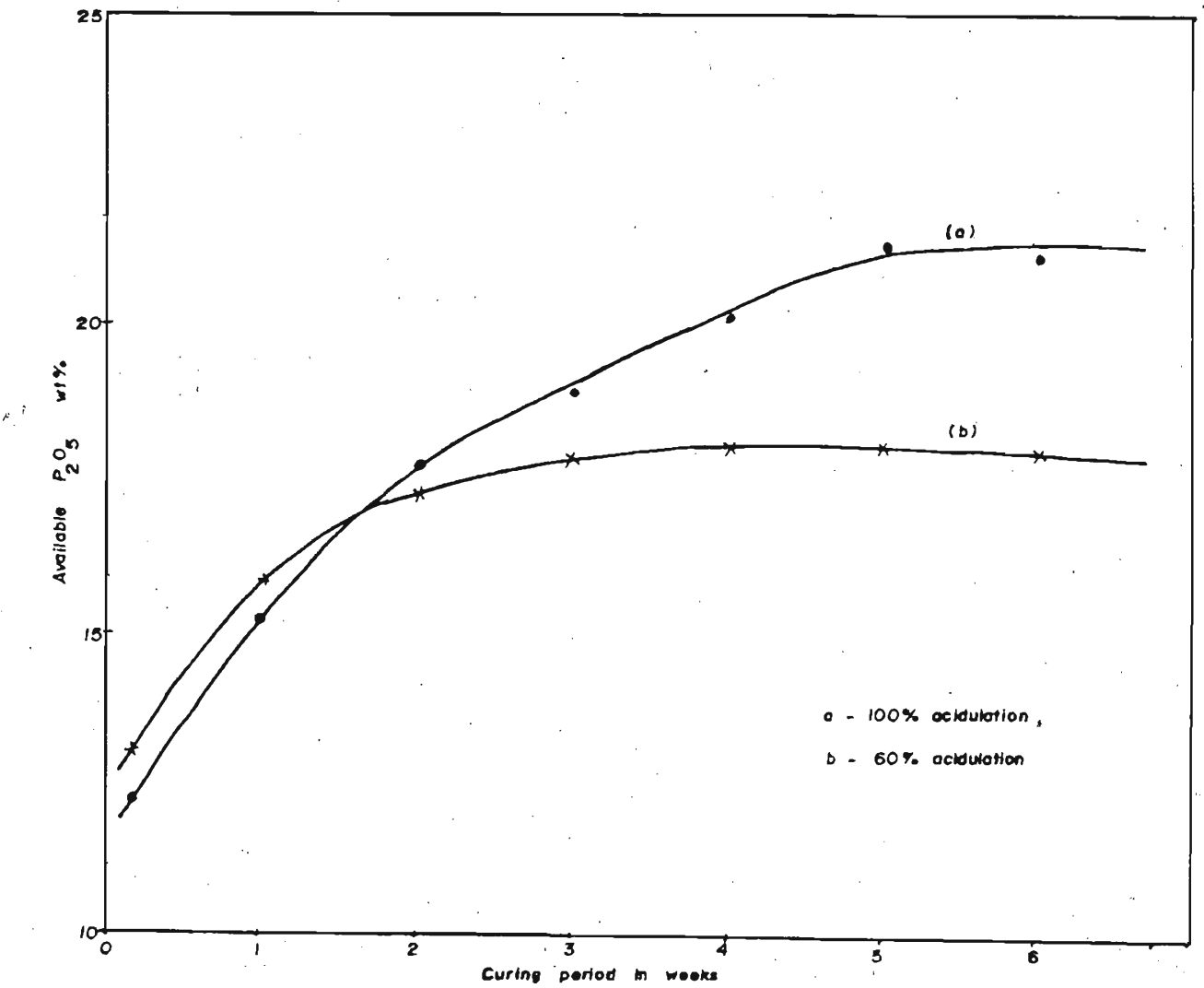

Figure 5. Effect of curing period on the available phosphorus content of the $\mathrm{H}_{2} \mathrm{SO}_{4}-$ acidulated product. 


\section{Discussion}

Phosphorus contents of the starting materials are compared with those of the major constituents in the fertilizer products in Table 5. Conditions of acidulation of Eppawela apatite are summarised in Table 6. For the production of $50 \%$ acidulated product, $30 \mathrm{~kg} \mathrm{H}_{2} \mathrm{SO}_{4}(100 \%$ basis $)$ diluted to $70 \%$ is required for $100 \mathrm{~kg}$ powdered apatite.

Direct acidulation of Eppawela rock phosphate with $\mathrm{HCl}$ to produce SSP is not feasible owing to the presence of large amounts of highly hygroscopic calcium chloride in the product. However, physical conditions of this product may be improved considerably by the subsequent treatment with ammonia or ammonium salts. A similar situation is anticipated in nitric acid acidulation to produce nitrophosphates. Nevertheless, $\mathrm{HCl}$ acidulation followed by alkali treatment produces $\mathrm{CaHPO}_{4}$ which can readily be used as $\mathrm{P}$-fertilizer. Use of $\mathrm{CaHPO}_{4}$ may be advantageous in areas where there is considerable leaching of phosphates.

Although lime is the cheapest alkali available, the use of lime in the $\mathrm{pH}$ adjustment is not recommended. Ammonia is an efficient neutralization agent because it facilitates the formation of dicalcium phosphate and the product contains another important plant nutrient, $N$. However, considering the availability and economic factors aqueous $\mathrm{NaOH}$ seems to be the most suitable.

In the case of sulphuric acid acidulation the major factor seems to be the cost of sulphuric acid. The cost of the final product will be dependent mainly on the cost and the amount of sulphuric acid used (extent of acidulation) in the process. When the extent of acidulation is less the cost will be lower and the total $\mathrm{P}_{2} \mathrm{O}_{5}$ content of the product will be more. On the other hand, the available $\mathrm{P}_{2} \mathrm{O}_{5}$ content or the fertilizer value increases with increase in the extent of acidulation.

On account of the large saving due to cutting down of acid requirement, and due to the presence of reasonably high phosphorus content of the partially acidulated product, this material can be considered as a potentially useful and economical phosphate fertilizer for Sri Lanka. Thus, $50 \%$ acidulation of Eppawela apatite with $\mathrm{H}_{2} \mathrm{SO}_{4}$ to produce partially acidulated phosphate rock (PAPR) containing about $17 \%$ wt available $\mathrm{P}_{2} \mathrm{O}_{5}$ and $25 \%$ total $\mathrm{P}_{2} \mathrm{O}_{5}$ appears to be suitable.

Free phosphoric acid content in the acidulated product plays an important role in fixing phosphates as aluminium and iron phosphates. Since the free phosphoric acid content is minimal in the partially acidulated product, the effect of the presence of $\mathrm{Al}_{2} \mathrm{O}_{3}$ and $\mathrm{Fe}_{2} \mathrm{O}_{3}$ is negligible in 


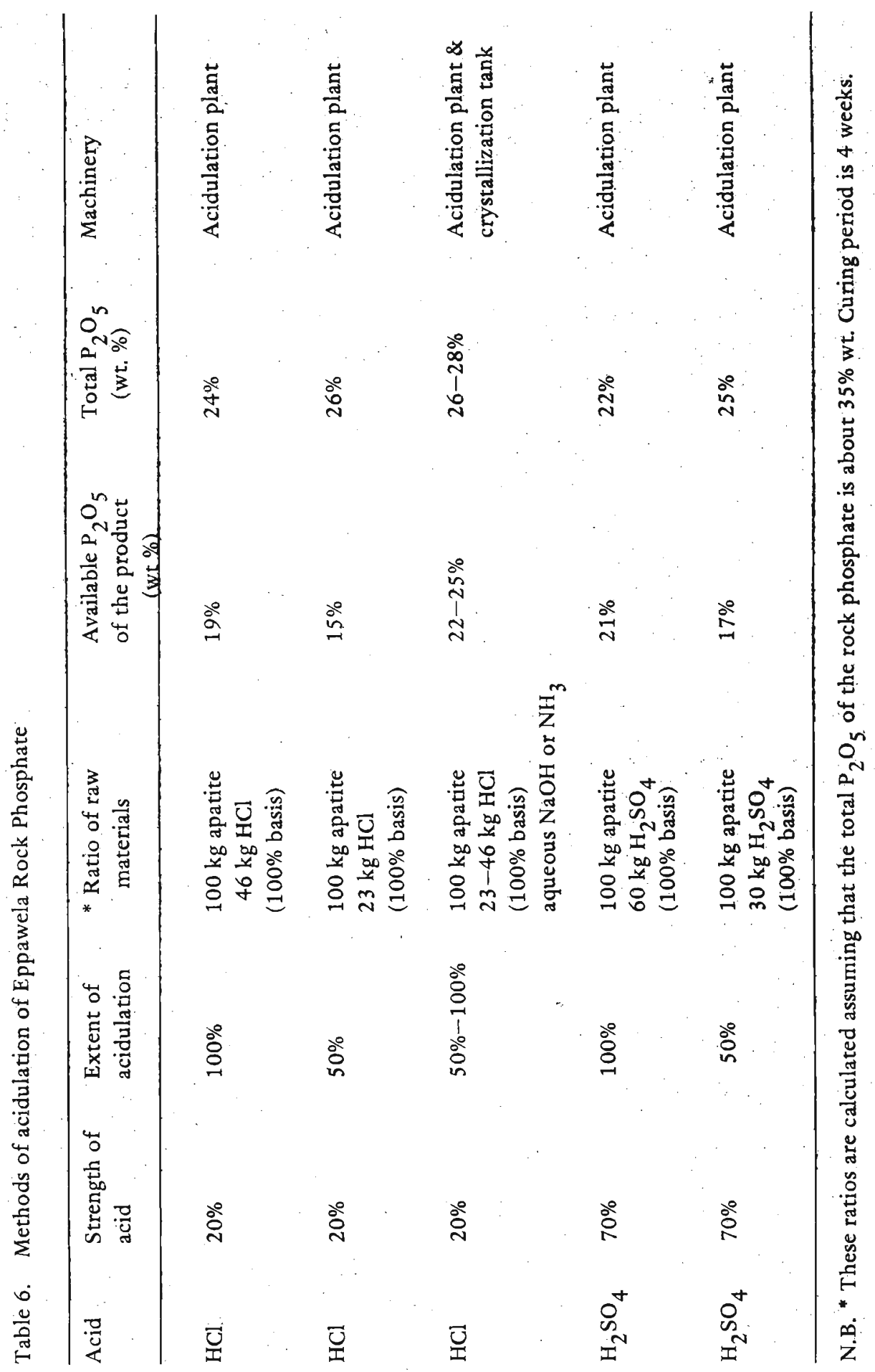


comparison with $100 \%$ acidulation to produce SSP.

Presence of high chlorine content in Eppawela apatite leads to corrosion problems in an industrial acidulation process. As such, mechanical mixers and the acidulation tanks should be lined with corrosion resistant material. Furthermore, pollution factors also should be taken into consideration in deciding the location of acidulation plants.

Although chemical tests and laboratory evaluations indicate that these products can be used as $\mathrm{P}$-fertilizers, it is essential to examine the crop response of the products and the financial viability of these processes. Therefore, pilot plant trials together with comprehensive financial evaluation of the processes and long-term field trials have to be carried out prior to commencement of any commercial production.

\section{Acknowledgement}

Author wishes to thank the International Seminar in Chemistry of the Uppsala University in Sweden for financial assistance to perform X-ray fluorescence analysis and powder X-ray diffraction.

\section{References}

1. EDMOND, C.R. (1969) Anal. Chem., 41 (10): 1327-1328.

2. GUNAWARDANE, R. P. (1982) J. Natn. Sci. Coun. Sri Lanka, 10 (2): 181-194.

3. GUNAWARDANE, R.P. (1987) J. Natn. Sci. Coun. Sri Lanka, 15 (1): in press.

4. GUNAWARDANE, R.P. \& GLASSER, F.P. (1979) J. Mater. Sci., 14: 2797-2816.

5. GUNAWARDANE, R.P. \& ANNERSTEN, H. (1987) J. Natn. Sci. Coun. Sri Lanka; 15 (2): in press.

6. JAYAWARDANA, D.E. DE S. (1976) The Eppawela carbonatite complex in NorthWest Sri Lanka, Economic Bulletin No.3, Geological Survey. Department of Sri Lanka, Colombo.

7. JAYASEKARA, K.S., TENNAKOON, D.T.B. \& GUNAWARDANE, R.P. (1978) Proc. Sri Lanka Assoc. Adv. Sci., 34: 59.

8. JAYASEKARA, K.S., TENNAKOON, D.T.B. \& GUNAWARDANE, R.P. (1978) Proc. Sri Lanka Assoc. Adv. Sri., 34: 60. 
9. JEFFERY, P.G. (1971) Chemical methods of rock analysis, Pergamon Press, Oxford.

10. MELLOR, J.W. (1971) Comprehensive treatise on inorganic and theoretical chemistry, Volume 3 - Supplement 3, Longmans, London.

11. PIERRE, W.H. \& NORMAN, A.G. (1953) Soil and fertilizer phosphorus in crop nutrition, Academic Press, London, New York. 